\title{
Discussion on the Cultivation of Students' Ability in Innovation and Entrepreneurship Competition
}

\author{
Chunfeng Jiang \\ Jilin Agricultural Science and Technology University, Jinlin China \\ hero_jcf@126.com
}

\begin{abstract}
Keywords: College students; Innovation and entrepreneurship; Competition; Students' ability; Training
\end{abstract}

\begin{abstract}
With the continuous development of China's economic social, all kinds of innovative talents are getting more and more attention and favor by the society. Students as a large number of talents about to enter to the society have received higher education, whose thoughts are with a higher layer of sublimation, are bound to the development of the society with to have very important influence, and gradually develop into the main force of personnel in all aspects of the society. So it is very necessary in the school to promote innovation and entrepreneurship education, under the new social situation and to strengthen the cultivation of College Students' innovation ability, which not only can help students solve the difficult employment problem, also can promote social development, improve the social productivity. It make students quickly adapt to the rapid development of social economy, take the initiative to adapt to the complicated and changeable social environment, more actively cope with the rapid development of society to graduate students to bring the challenges, to realize the flexible employment of the college students, which is a new era of society to give universities a new mission. In this paper, starting from the college students' innovation and entrepreneurship competition, analyzed the relevant.
\end{abstract}

\section{Introduction}

In the form of the continuous development of China's social and economic, it is necessary to strengthen the cultivation of College Students' innovation and entrepreneurship ability, which is not only related to the future of College Students' employment problem, for college students' innovation ability is a very good training and development opportunities, as to make the students better and faster adapt to social and economic development speed, assume from school transition to social responsibility. Therefore, to strengthen the cultivation of the ability of College Students' innovation and entrepreneurship is an important task of now cultivating talents in Colleges and universities. Colleges and universities to carry out comprehensive and effective education innovation and entrepreneurship education, Let more and more students have the courage and the ability to choose entrepreneurship, facing the difficulties in the future, can be positive coping can well adapt to different school complex and changing social environment, to realize the college students' personal ideal of entrepreneurship. At the same time, the innovation and Entrepreneurship of university students have further promoted the economic development in all aspects of the society, and it is also a higher expectation for higher education in the country and society.

\section{The Reasons of Cultivating the Ability of Contemporary College Students' Innovation and Entrepreneurship}

In view of the reasons for cultivating the ability of contemporary college students' innovation and Entrepreneurship, it can be divided into the following aspects to analyze and research:

College Students' Employment Situation Is Complicated in Real Society. In the real society, the employment situation of college students is a complex problem which we are not difficult to find in our daily life. Nowadays, the situation of employment is becoming more and more serious, and the number of colleges and universities in our country has increased, so that every year the graduates of colleges and universities have increased sharply. In this growing social situation, in 
order to avoid the difficulty of College Students' employment situation, promoting college students' entrepreneurship has become a very important way to solve the situation. Today, the state and the government every year for the university graduates to start a series of supportive policies and preferential policies, has prompted a lot of graduates to change in the employment concept. More and more college graduates choose to start a business, in accordance with the current form, college students' starting a business will become the future choice of employment of College students. The success rate of College Students' entrepreneurship is the focus of many people's attention, to ensure the success rate of college students, it is required to have the spirit of hard work, and the most important thing is to have a unique spirit of innovation. In a creative society, the contemporary university graduates only improve their comprehensive quality, enrich their own innovative ideas so that they can firm heel and stand out from the many entrepreneurs to success in the rapid development of innovative social. Therefore, it is very important for the society and college students to cultivate the contemporary college students' innovative and entrepreneurial ability.

Demand for the Development of the Socialist Market Economy. In view of the complicated situation of College Students' employment in real society, firstly, we should analyze the development of socialist market economy in today's society, the continuous developing of social status and ascension causes that many of the development of industrial structure is unstable, and job is also very unstable which brings just out college students a very bad influence. At the same time, many jobs need more talents with innovative ability, and college students as the main force of today's employment should have the innovation ability, in order to adapt to the development of socialist market economy, must strengthen the cultivation of College Students' innovation ability. Only the university students' innovation and entrepreneurship awareness can be effective trained, can the road be a more stable in the future employment.

In the view of the reform of talent cultivation mode in Colleges and universities for the demand social development, First of all, it can be analyzed that a new type of society needs a lot of innovative talents. College graduates in the community employment quality, only continuous innovation promote the sound development of all aspects of society, in to promote national progress, so that China became the world's influential countries. The cultivation of talents is a new innovative form training, learning the knowledge in the future in the university campus is to realize their own value in the society. In the reform of university teaching, we should spread the awareness of innovation and entrepreneurship competition effectively, only the concept of communication, can be effective to ensure students' independent innovation and entrepreneurial ideas. Therefore, the country needs more innovative talents to come out of the school gate to the society, and serve the country and society.

\section{Promoting the Practical Application of College Students' Innovative and Entrepreneurial Ability}

The practical application problem of improving the cultivation of College students' innovative and entrepreneurial ability can be divided into the following aspects to analyze and discuss:

Improve the Construction of Innovation and Entrepreneurship knowledges about the University Students' Life. For the problems of improving the construction of the innovation and entrepreneurship knowledge about university life, we should strengthen the construction of the teaching staff and cultivate the quality of innovation and entrepreneurship. In real life, college students' learning channels are different, and the construction status of related innovative entrepreneurial knowledge is also different. College students grow up in different colleges and universities and follow different teachers to learn different knowledge; teachers as the guidance of students to obtain knowledge, their own quality and ability is very important. Therefore, the major colleges and universities before cultivating students' ability of innovation and entrepreneurship must strengthen the construction of entrepreneurial education teachers. Only with high quality and innovative awareness of the teacher, can we drive students to a profound understanding of innovation and entrepreneurship at the root and be effective to cultivate more innovative and entrepreneurial College students. College students in the university education are to get an effective 
guarantee in the future social life, whose life should be full with innovation and challenge. Because of the improvement of the country's economic construction ability, the relevant economic level is also constantly improving, for this economic status, college students in the school study, should reasonably analyze and research the reality of social and economic conditions. For the efficient construction of current college students' innovational ideas, in college life, college students should reasonably research and plan with the related school teachers according to their own new entrepreneurial thinking and improve their innovation ideas with the teachers' help. Only in this way, careful and cautious innovation and Entrepreneurship ideas of college students can gain a firm foothold in the future development of college students.

Realize the Construction of Innovation and Entrepreneurship Education Curriculum System. For the problem of realizing the construction of the innovation and entrepreneurship education curriculum system, a reasonable innovation and entrepreneurship education system should be constructed based on university life. Compared with the traditional university knowledge, innovation and entrepreneurship need more the new knowledge and new ideas outside of books. Previous knowledge in the course is very difficult for the contemporary college students in the innovative society to get a good development, and the traditional book knowledge is dry and tasteless making it difficult for college students really learn professional knowledge, which results that college graduates cannot be successful for them to find the right work with their own knowledge related. Therefore, it is necessary to build a curriculum system of entrepreneurship education in Colleges and universities, to eliminate the boring learning atmosphere and professional knowledge, and from various aspects to cultivate students' innovation and Entrepreneurship ability. For cultivating college students' ability of innovation and entrepreneurship, the curriculum is very important. Universities must get rid of the traditional teaching mode, to develop a good and innovative entrepreneurship related courses and Practice. For the teaching of bold innovation and reform, in particular, should pay attention to the students' practical ability, so that students can learn from the practice of real knowledge and methods. Schools should be appropriate to open innovation and entrepreneurship education courses and lectures, so that students more exposure to the real situation of the community, to explore innovative thinking and vision of College students. Schools should provide opening thinking of learning and practice environment for students, not in completely immersed in the paper knowledge, so that students in school can come into contact with some of the social atmosphere, so as to achieve in school to learn knowledge can be better applied to social practice and work, the ability to entrepreneurship can get a comprehensive upgrade.

Strengthen the Practice Activities of College Students' Innovation and Entrepreneurship. In view of the problem of strengthening the practical activities of College Students' innovation and entrepreneurship, it can be carried out from the school life of university students. In the school, the university students innovation and entrepreneurship base can be established, which urges students to carry out more social practical activities. In order to improve students' consciousness and ability, we must through various social practice and experience, from themselves to cultivate the innovation and entrepreneurship psychological characteristics and ideas. School with society of small and medium enterprises reached a cooperative relationship, recommend outstanding college students into corporate social practice, to experience the working atmosphere and environment for innovative enterprises, fundamentally improving the quality and the thoughts of the entrepreneurs. Schools should actively organize students to participate in all kinds of innovative competitions and activities, to constantly improve their own thinking mode, as well as the observation and implementation force of the various aspects and continuous strengthen College Students' innovation awareness, training more innovative and entrepreneurial talents. Students can also put forward the project application from the school, according to their own creative ideas and a ability to start small companies or business in the school. At the same time, the school can also organize students to participate actively with the outside entrepreneurial practice base, make every students have access to the whole process of innovation and entrepreneurship, early taste of market operation risk, learn to control risk, grasp market operation method and market all aspects of information and better achieve the teaching effect of College Students' innovation and entrepreneurship, also let the 
students comprehend and learn more innovative entrepreneurial knowledge, lay a strong foundation for future business to the existing competitive situation, to meet more challenges in the future.

\section{Summary}

With the continuous construction of the city, the relevant innovative consciousness constantly strengthening, college Students in real life, becoming the main employment population, in the direction of the employment population, the school should be effective in the learning guide. Today's society is a innovative era, United Nations Educational, scientific and Cultural Organization (UNESCO) clearly pointed out that colleges and universities must put the innovation and entrepreneurship as the basic objectives of the higher education, to make college graduates become the creator of jobs. Under the new social situation, the school must open the field of vision and control the difficult employment of College students. Innovation and entrepreneurship development of higher education, as a new mode of education is the most important part of the contemporary social development, is the most time to demand of talent in today's society, so college students should be a good time to grasp the development of the current. At the same time, students should seize the opportunity to study in the school innovation and entrepreneurship, as much as possible to broaden their horizons, and dare to try, innovate, venture. Students should be through their own rich ideas, more understanding of market development, identifying the opportunity to find a suitable way to start their own business, in the process of self-innovation, with continuous innovation, so that their innovation more competitive, so as to the success of innovation and entrepreneurship. Therefore, innovation and entrepreneurship education is the demand of the society, the needs of the motherland, so colleges and universities should develop innovative entrepreneurship education, cultivate students' ability of innovation and entrepreneurship, cultivate innovative awareness, to meet the challenges of the new situation in the new society.

\section{References}

[1] Qiu Wenwei. The cultivation and promotion of innovation and entrepreneurship ability of College Students -- Based on the functional effect of the discipline competition $[\mathrm{J}]$. The modern economy, 2015, 01: 107-109.

[2] Dang Yuanyi. Talking about the cultivation of students' ability in innovation and entrepreneurship competition [J].Business Herald, 2015, 02: 117+119.

[3] Li Qingquan Zheng Jifeng. Entrepreneurship Program competition on the cultivation of College Students' innovative and entrepreneurial ability- Taking Hunan University of Science and Engineering as an example [J]. Journal of Hunan University of Science and Engineering, 2011,12:137-139

[4] He Bing, Qin Ming. Relying on the science and engineering discipline competition, Promoting the cultivation of students' innovative and entrepreneurial ability-Taking the Department of physics and telecommunication engineering of Baise University as an example [J].Journal of Baise University, 2015,06:150-152.

[5] Liu Xiling, Chen Liuqiang, Zou Cheng. Discuss on the cultivation of students' creative ability in the independent college mathematical modeling contest [J].China Electric Power Education, 2014, 02:55-56.

[6] Jiang Jianhong, Xiao Shengxiong, Xiangke Hu Chaosu, Xiao Biyuan, Ye Lijuan, , Liu Wenqi. Discuss on "challenge the cultivation of innovation ability of local college students' Cup competition in [J].Guangdong chemical industry, 2014, 20: 176-177.

[7] Xie Hongmei, Geng Kuihua Subject competition as the carrier, cultivate four kinds of abilities of College Students-- take the school of mechanical engineering of Guangxi University as an example [J]Higher education forum, 2013,08:47-50. 
[8] Gao Ying. Discuss on the cultivation of College Students' ability of innovation, creativity and entrepreneurship in our college-College entrepreneurship program network virtual operations challenge as an opportunity [J].Heilongjiang science and technology information, 2012, 31:234.

[9] Ling Shan, He Chengdong, Cui Xiaofeng. Discuss on the role of "Challenge Cup" competition on the cultivation of students' innovative ability and practical ability [J] China training, 2016, $06: 144$.

[10] Gao Yun, Wang Wei, Liang Xiuying. Talking about the electronic design competition and the cultivation of students' creative ability in agricultural engineering major [J].Hubei agricultural mechanization, 2008,06:30- 